\title{
Potencialidades do uso do ozônio no processamento de alimentos
}

\section{Potential use of ozone in the food processing}

\author{
Suse Botelho da Silva ${ }^{*}$; Márcia de Mello Luvielmo²; Mariana Curtinovi Geyer ${ }^{3}$; \\ Ivana Prá ${ }^{4}$
}

\section{Resumo}

O ozônio é um gás incolor de odor pungente, instável e parcialmente solúvel em água, que se destaca por seu elevado poder oxidante. É um forte agente desinfetante com ação sobre uma grande variedade de organismos patogênicos, incluindo bactérias, vírus e protozoários, apresentado uma eficiência germicida que excede ao cloro. $\mathrm{O}$ uso do ozônio tornou-se notório nas últimas décadas em função da implementação de padrões cada vez mais restritos em relação aos subprodutos da cloração. Ao contrário do cloro, o ozônio não forma subprodutos halogenados com a matéria orgânica, mas pode induzir a formação de outros subprodutos orgânicos e inorgânicos. Na indústria de alimentos, o ozônio pode ser utilizado em processos de sanitização de superfícies e equipamentos, bem como no uso direto sobre as matérias-primas com o objetivo de inativar microrganismos e aumentar a vida-de-prateleira dos produtos alimentícios.

Palavras-chave: Ozônio. Agente oxidante. Inativação microbiana. Alimentos.

\begin{abstract}
Ozone is a colorless and unstable gas with pungent smell and partially soluble in water, which is characterized by its high oxidant power. It is a strong agent disinfectant with high power germicidal properties acting in the inactivation of a wide variety of pathogenic organisms, including bacteria, virus and protozoa, presenting a germicidal efficiency that exceeds chlorine. Ozonization has become wellknown in recent decades due to implementation of standards increasingly restrictive concerning the by-products of chlorination. Unlike chlorine, ozone do not form halogenated compounds with organic matter. However, it may form several other organic and inorganic. In the food industry, ozone can be use in sanitization processes of equipments and surfaces, as well as in the direct use on foodstuff in order to inactivate microorganisms and to extend shelf-life of food products.
\end{abstract}

Key words: Ozone. Oxidant agent. Microbial inactivation. Food.

1 Prof. Adjunto da área de Ciências Exatas e Tecnológicas, Engenharia de Alimentos, Universidade do Vale do Rio dos Sinos, UNISINOS. E-mail: susebs@unisinos.br

2 Prof. Adjunto do Dept ${ }^{0}$ de Ciência de Alimentos, Química de Alimentos, Universidade Federal de Pelotas, UFPEL. E-mail: mmluvielmo@gmail.com

3 Graduado em Engenheira de Alimentos, Universidade do Vale do Rio dos Sinos, UNISINOS. E-mail: marianageyer@terra.com. br

${ }^{4}$ Graduado em Engenheira de Alimentos, Universidade do Vale do Rio dos Sinos, UNISINOS. E-mail: enoipra@yahoo.com.br

* Autor para correspondência 


\section{Introdução}

A ação germicida do ozônio foi evidenciada na França, no final do século XIX, quando este gás começou a ser utilizado como desinfetante no tratamento de água (LAPOLLI et al., 2003; RICE et al., 1981). Desde então, tem sido estudado e aplicado intensamente na purificação e desinfecção de água (RICE et al., 1981), principalmente na Europa. As técnicas de ozonização foram desenvolvidas mais significativamente nos últimos 40 anos, particularmente na França, na Alemanha Ocidental e na Suíça (LAPOLLI et al., 2003). Nos Estados Unidos, o interesse pelo processo de ozonização no tratamento de águas iniciou-se após a identificação dos compostos halogenados que são gerados a partir da cloração (RICE et al., 1981).

O ozônio foi descoberto em 1839, por Schonbein que estudava a decomposição eletrolítica da água (LAPOLLI et al., 2003). Em 1848, Hunt concluiu que o ozônio era a forma alotrópica do oxigênio (VIDAL, 2003; RUSSEL; HUGO; AVLIFFE, 1999), sendo que uma década após ficou claramente identificada sua composição triatômica. Em 1857, Werner Von Siemens identificou a possibilidade de gerar ozônio a partir de descarga elétrica em meio gasoso. O ozônio foi reconhecido como um potente desinfetante de água em 1866, por Meritens (LAPOLLI et al., 2003; LANGLAIS; RECKHOW; BRINK, 1991). Na Alemanha em 1875, foi criado o primeiro gerador de ozônio (TORRES; REGÊ FERREIRA; RÍMOLI, 1996). Em 1889, o químico francês Marius Paul Otto iniciou os estudos sobre a atividade germicida do ozônio na Universidade de Sorbone, Paris (LANGLAIS; RECKHOW; BRINK, 1991). Testes em escala piloto na Alemanha em 1981 mostraram a efetiva ação do ozônio contra bactérias (LAPOLLI et al., 2003; LANGLAIS; RECKHOW; BRINK, 1991).

O ozônio teve a primeira aplicação em grande escala no tratamento de água em 1893 em Oudshoorn, na Holanda (LAPOLLI et al., 2003; LANGLAIS; RECKHOW; BRINK, 1991).
Marius Paul Otto, em 1897, criou a primeira companhia especializada na construção e instalação de equipamentos de ozonização para tratamento de água (LAPOLLI et al., 2003). A partir deste momento, plantas de tratamento de água foram construídas em Paris (1898 e 1909), Nice (1906) e Chartres (1908) na França; Wiesbaden (1901) e Paderborn (1902) na Alemanha; Niagara (1903) no estado de Nova Yorque nos Estados Unidos; São Petesburgo (1905) na antiga União Soviética e Madri (1910) na Espanha. O número de instalações cresceu rapidamente a partir de 1914, sendo que em 1936 haviam cerca de 100 estações de tratamento de água na França e cerca de 30 a 40 em outras partes do mundo (LANGLAIS; RECKHOW; BRINK, 1991). Desde então, o ozônio vem sendo utilizado no tratamento de água para abastecimento público na Europa (GUZEL-SEYDIM; GREENE; SEYDIM, 2004; GRAHAM, 1997).

Em 1982, o ozônio foi considerado como um produto seguro ("General Recognized As Safe" GRAS) para o tratamento de garrafas de água pela FDA (Food and Drug Administration), sendo que uma série de outras aplicações comerciais foram desenvolvidas, incluindo a desinfecção de água de piscina e o tratamento de águas residuais (GUZELSEYDIM; GREENE; SEYDIN, 2004; RUSSEL; HUGO; AVLIFFE, 1999). Na década de 90, os Estados Unidos afirmaram o ozônio como uma substância GRAS para aplicação direta em produtos alimentícios. A partir deste momento, houve um crescente interesse na aplicação de ozônio no processamento de alimentos (GRAHAM, 1997).

A ozonização passou a ser utilizada no Brasil como alternativa aos métodos convencionais de pré-cloração e pré-aeração no tratamento de águas superficiais a partir de 1983 (LAPOLLI et al., 2003). Na área de alimentos, poucas pesquisas têm sido realizadas no Brasil e ainda não existe legislação específica que oriente aplicações nesta área. O presente artigo faz uma revisão a respeito das propriedades físicas e químicas do ozônio, bem como dos processos de geração, metodologias de 
mensuração do ozônio residual, decomposição e geração de subprodutos. O ozônio é apresentado como um sanitizante alternativo ao cloro, sendo detalhado seu efeito sobre diversos grupos de microrganismos. Alguns estudos do uso do ozônio no processamento de alimentos são descritos, bem como as principais limitações desta tecnologia.

\section{Propriedades físicas e químicas do ozônio}

O ozônio, que se apresenta na forma triatômica do oxigênio $\left(\mathrm{O}_{3}\right)$, é um gás extremamente instável e parcialmente solúvel em água (DI BERNARDO;
DANTAS, 2005; LAPOLLI et al., 2003; RUSSEL; HUGO; AVLIFFE, 1999). O gás ozônio possui odor penetrante e é facilmente detectável em concentrações muito baixas $(0,01$ a $0,05 \mathrm{mg} / \mathrm{L})$ (LAPOLLI et al., 2003; RICE et al., 1981).

Quando comparado a outros agentes oxidantes, o ozônio se destaca pelo elevado potencial de oxidação $(2,07 \mathrm{mV})$. O ozônio é o segundo mais poderoso agente oxidante, perdendo apenas para o flúor $(3,06$ mV) (LAPOLLI et al., 2003; RUSSEL; HUGO; AVLIFFE, 1999). Na Tabela 1 são mostrados os valores dos potenciais de oxidação de diferentes agentes oxidantes.

Tabela 1. Agentes oxidantes e respectivos potenciais de oxidação.

\begin{tabular}{lc}
\hline Agente oxidante & Potencial de oxidação $(\mathbf{m V})$ \\
\hline Flúor & 3,06 \\
Ozônio & 2,07 \\
Peróxido de hidrogênio & 1,78 \\
Permanganato & 1,67 \\
Dióxido de cloro & 1,50 \\
Hipoclorito & 1,49 \\
Cloro & 1,36 \\
\hline
\end{tabular}

Fonte: Manley et al. (1967) apud Guzel-Seydim, Greene e Seydim (2004).

O ozônio a temperatura ambiente e em baixas concentrações, apresenta-se como um gás incolor; já em altas concentrações adquire uma coloração azulada. Com o aumento da temperatura, o ozônio tem sua solubilidade em água reduzida, tornando-se menos estável (SILVEIRA, 2004; LAPOLLI et al., 2003; USEPA, 1999; LANGLAIS; RECKHOW; BRINK, 1991). Porém o aumento na temperatura não altera expressivamente a taxa de desinfecção do ozônio, com isso percebe-se que a desinfecção é relativamente independente da temperatura (SILVEIRA, 2004; LAPOLLI et al., 2003; USEPA, 1999; LANGLAIS; RECKHOW; BRINK, 1991).

Um valor de $\mathrm{pH}$ elevado favorece a decomposição do ozônio e a formação de diferentes tipos de compostos oxidantes com reatividades diferentes, como radicais livres hidroxila (elevado poder de oxidação) (DI BERNARDO; DANTAS, 2005; LAPOLLI et al., 2003). Além da temperatura e do $\mathrm{pH}$, a radiação ultravioleta ou a presença de catalisadores a base de paládio, manganês e óxido de níquel, assim como metais, óxidos de metais, hidróxidos e peróxidos aceleram a decomposição do ozônio (LAPOLLI et al., 2003; LANGLAIS; RECKHOW; BRINK, 1991).

O ozônio é relativamente instável em solução aquosa e apresenta meia-vida que varia de 20 a $30 \mathrm{~min}$ em água destilada a $20^{\circ} \mathrm{C}$ (VIDAL, 2003; KHADRE; YOUSEF; KIM, 2001; WICKRAMANAYAKE, 1991), embora alguns autores já tenham reportado 
uma meia-vida de 165 min (DI BERNARDO; DANTAS, 2005; VIDAL, 2003; KHADRE; YOUSEF; KIM, 2001; RICE et al., 1981). Já em fase gasosa, o ozônio é mais estável; sua meia-vida no ar atmosférico, medida pela Agência de Proteção Ambiental dos Estados Unidos, é da ordem de $12 \mathrm{~h}$ (DI BERNARDO; DANTAS, 2005; VIDAL, 2003; RUSSEL; HUGO; AVLIFFE, 1999; GRAHAM,
1997; WICKRAMANAYAKE, 1991; RICE et al., 1981).

O ozônio apresenta massa molar de $48 \mathrm{Da}$ e condensa a $-111,9{ }^{\circ} \mathrm{C}$ (RUSSEL; HUGO; AVLIFFE, 1999). A Tabela 2 apresenta as principais propriedades físico-químicas desse gás.

Tabela 2. Principais propriedades físico-químicas do ozônio.

\begin{tabular}{lr}
\hline \multicolumn{2}{c}{ Propriedades físico-químicas } \\
\hline Massa molar & $48 \mathrm{Da}$ \\
Massa específica $\left(0^{\circ} \mathrm{C}\right.$ e $\left.101,3 \mathrm{kPa}\right)$ & $2,154 \mathrm{~kg} / \mathrm{m}^{3}$ \\
Ponto de ebulição & $-111,9 \pm 0,3{ }^{\circ} \mathrm{C}$ \\
Ponto de fusão & $-192,5 \pm 0,3{ }^{\circ} \mathrm{C}$ \\
Solubilidade em água a $0{ }^{\circ} \mathrm{C}$ & $20 \mathrm{~g} / \mathrm{m}^{3}$ \\
Solubilidade em água a $30^{\circ} \mathrm{C}$ & $1,5 \mathrm{~g} / \mathrm{m}^{3}$ \\
Temperatura crítica & $-12,1{ }^{\circ} \mathrm{C}$ \\
Pressão crítica & $5,53 \mathrm{MPa}$ \\
\hline
\end{tabular}

Fonte: Vidal (2003); Manley et al. (1967 apud Guzel-Seydim; Greene e Seydim, 2004).

A molécula de ozônio é produzida a partir do oxigênio elementar e tem caráter metaestável (LAPOLLI et al., 2003; LANGLAIS; RECKHOW;
BRINK, 1991). A Figura 1 apresenta as possíveis formas da estrutura molecular do ozônio devido à ressonância magnética.


Figura 1. Estrutura molecular do ozônio devido à ressonância magnética.

A molécula de ozônio pode agir como um dipolo, como um agente eletrofílico ou como um agente nucleofílico. A reação eletrofílica é restrita a locais na molécula que apresentam uma alta densidade eletrônica e, em particular, a algumas combinações aromáticas. Substitutos aromáticos com grupo de elétrons doadores $\left(\mathrm{OH}, \mathrm{NH}_{2}\right.$ e compostos similares) mostram alta densidade eletrônica nos carbonos localizados na posição orto e são altamente reativos nesta posição. Ao contrário, os substitutos aromáticos sem grupo de elétrons doadores reagem fracamente com o ozônio. Neste caso, o ataque 
inicial do ozônio molecular acontece principalmente na posição para. As reações nucleofílicas são encontradas em sítios moleculares que mostram um déficit eletrônico, principalmente nos carbonos que não apresentam grupos de elétrons doadores. As reações com ozônio molecular são extremamente seletivas e limitadas aos componentes aromáticos insaturados e alifáticos como também aos grupos funcionais específicos (VIDAL, 2003; LANGLAIS; RECKHOW; BRINK, 1991).

Em solução aquosa, o ozônio pode reagir com os compostos orgânicos através de reações diretas, as quais envolvem o ozônio molecular ou através de reações indiretas que envolvem reações com os radicais hidroxila $\left(\mathrm{OH}^{\circ}\right)$ formados da decomposição do ozônio (DI BERNARDO; DANTAS, 2005; VIDAL, 2003; USEPA, 1999; LANGLAIS; RECKHOW; BRINK, 1991).

Ambos os mecanismos de ação do ozônio competem pelo substrato (composto a ser oxidado). As reações diretas do ozônio molecular com os compostos dissolvidos são bastante lentas e seletivas. Devido a este caráter seletivo, pequenas doses de ozônio produzem grande efeito sobre determinadas etapas em sistema de tratamento de águas e efluentes (DI BERNARDO; DANTAS, 2005; USEPA, 1999; LANGLAIS; RECKHOW; BRINK, 1991). As reações indiretas são muito rápidas, porém não seletivas, a hidroxilação geralmente é seguida da abertura do ciclo aromático, levando a formação de aldeídos, acetonas e ácidos (VIDAL, 2003).

\section{Geração do ozônio}

A reação global para geração do ozônio a partir do oxigênio pode ser descrita como:

$$
3 \mathrm{O}_{2} \leftrightarrow 2 \mathrm{O}_{3} \quad \Delta \mathrm{H}=+284,5 \mathrm{~kJ} / \mathrm{mol}
$$

A reação (1) é altamente endotérmica e não é espontânea $(\Delta \mathrm{G}=+161,3 \mathrm{~kJ} / \mathrm{mol})$, isto porque o ozônio não pode ser gerado pela ativação térmica do oxigênio, uma vez que o ozônio se decompõem rapidamente quando aquecido (VIDAL, 2003)

O ozônio é formado naturalmente na estratosfera em pequenas quantidades $(0,05 \mathrm{mg} / \mathrm{L})$ pela ação da radiação ultravioleta do sol sobre o oxigênio. Uma pequena quantidade de ozônio também é formada na troposfera como subproduto das reações fotoquímicas entre hidrocarbonetos, oxigênio e nitrogênio que são lançados por automóveis, indústrias, florestas e ação vulcânica. Porém, o gás produzido é muito instável e decompõe-se rapidamente no ar (HORVATH et al., 1985 apud PRESTES, 2007).

Para a geração de ozônio, deve-se dividir primeiramente uma molécula de oxigênio diatômico. O oxigênio livre resultante da quebra da molécula de oxigênio pode reagir com outras moléculas de oxigênio para formar as moléculas de ozônio. Porém para quebrar a molécula de oxigênio uma grande quantidade de energia é requerida (RUSSEL; HUGO; AVLIFFE, 1999; USEPA, 1999). O ozônio pode ser produzido por métodos fotoquímico e de descarga elétrica, além disso, ainda pode ser produzido por método térmico, radioquímico e eletroquímico (KIM; YOUSEF; DAVE, 1999; LANGLAIS; RECKHOW; BRINK, 1991).

A geração fotoquímica do ozônio ocorre mediante a reação do oxigênio do ar sob luz ultravioleta a um comprimento de onda de 140 a 190 $\mathrm{nm}$. Este método de geração ocorre naturalmente na estratosfera e pode ser reproduzido em laboratório através da radiação emitida por lâmpadas do tipo ultravioleta. Esse procedimento não é utilizado industrialmente devido ao baixo rendimento e ao elevado consumo energético (VIDAL, 2003; LANGLAIS; RECKHOW; BRINK, 1991).

A produção comercial do ozônio é realizada pelo processo de descarga elétrica, também chamado de processo corona (RUSSEL; HUGO; AVLIFFE, 1999; USEPA, 1999). Um gerador de ozônio que 
utiliza o processo corona é constituído por dois eletrodos submetidos a uma elevada diferença de potencial (aproximadamente $1000 \mathrm{~V}$ ). O ozônio é gerado pela passagem de ar ou oxigênio puro entre os dois eletrodos. Quando os elétrons possuem energia suficiente para dissociar a molécula de oxigênio, começam a ocorrer colisões, que causam a dissociação do oxigênio e a conseqüente formação do ozônio (USEPA, 1999). Na Figura 2, pode-se observar um esquema de um gerador de ozônio pelo processo corona.
Devido à grande instabilidade do ozônio é necessário gerá-lo no local onde será usado, pois quando exposto ao ar, o gás se decompõe rapidamente (LAPOLLI et al., 2003; RUSSEL; HUGO; AVLIFFE, 1999; USEPA, 1999). No processo corona, a produção de ozônio varia dependendo da diferença de potencial, da freqüência da corrente elétrica, da constante dielétrica e do espaço de separação entre os eletrodos (ROSEN, 1972 apud KIM; YOUSEF; DAVE, 1999).

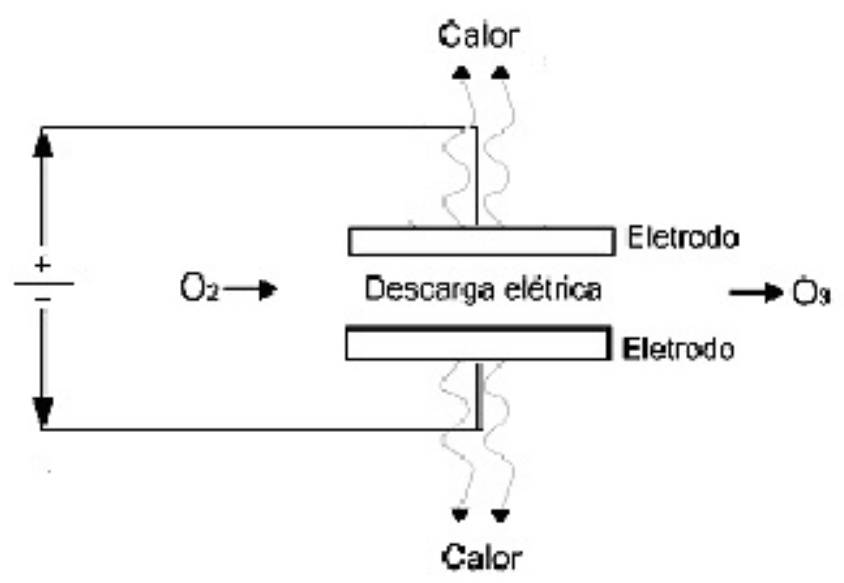

Figura 2. Geração do ozônio através do processo corona

O processo corona pode converter oxigênio molecular em ozônio a concentrações de até $4 \%$ em massa para geração a partir de ar e de até 14\% para geração a partir do oxigênio puro (RICE, 1996 apud KUNZ et al., 1999). Para a geração de ozônio, a partir do ar geralmente é necessário seu pré-tratamento, que inclui etapas de filtração, compressão, resfriamento e desumidificação. Já a geração a partir do oxigênio é realizada alimentando o gerador de ozônio a partir de um tanque de oxigênio líquido precedido de um evaporador. As vantagens de utilizar um ozonizador alimentado com oxigênio são o menor custo de manutenção, devido à maior simplicidade do equipamento e maior rendimento no processo de transformação de oxigênio em ozônio. Porém, a desvantagem é o alto custo do oxigênio (LAPOLLI et al., 2003).
Em outra técnica implementada para produzir o ozônio, o fabricante reivindica que o sistema produz ozônio a concentrações que são de três a quatro vezes mais altas (10 a 18\% de ozônio na produção da mistura gasosa) que os níveis atingíveis através de descarga corona. Nesta técnica, o ozônio é produzido por método eletroquímico, no qual a água é convertida em hidrogênio e átomos de oxigênio através de eletrólise. As moléculas de hidrogênio são separadas do gás e da água e os átomos de oxigênio se combinam para formar ozônio e oxigênio diatômico. (LYNNTECH, 1998 apud KIM; YOUSEF; DAVE, 1999).

\section{Mensuração do ozônio residual}

A análise precisa da quantidade de ozônio residual presente na fase gasosa ou na fase líquida 
é de extrema importância, especialmente para determinação da dose de ozônio a ser aplicada. A possibilidade de uma adequada mensuração do ozônio refletirá no custo, na eficiência, na segurança e na melhoria do projeto e da construção de geradores de ozônio (USEPA, 1999; WICKRAMANAYAKE, 1991).

Os métodos analíticos para a determinação de ozônio podem ser divididos em físicos, físicoquímicos e químicos. Os métodos físicos se baseiam na medição das propriedades particulares do ozônio, tais como a intensidade de absorção de radiação ultravioleta na região do visível ou infravermelha do espectro. Os métodos físico-químicos medem efeitos físicos da reação do ozônio com diferentes reativos, tais como na quimiofluorescência. Já os métodos químicos medem a quantidade dos produtos de reação que são liberados quando ozônio reage com um reativo apropriado ou medem a redução na massa molar de um polímero. Estes métodos diferem em sensibilidade e precisão (KHADRE; YOUSEF; KIM, 2001).

\section{Mensuração do ozônio residual na fase líquida}

Método espectrofotométrico - método do índigo

O método do índigo é mais sensível, preciso, rápido e seletivo que outros métodos geralmente utilizados para a determinação do ozônio residual. Os íons de manganês e cloro, peróxido de hidrogênio, produtos da decomposição do ozônio e os produtos da ozonização de solutos orgânicos apresentam menos interferência no procedimento com o índigo, do que em outros métodos, como no método iodométrico. Porém, a presença de cloro pode mascarar o ozônio tornando o método índigo problemático (USEPA, 1999; LANGLAIS; RECKHOW; BRINK, 1991).

No método do índigo, uma solução estoque de índigo é preparada usando ácido fosfórico e índigo trissulfonato de potássio. Esta solução é estável quando armazenada no escuro por períodos de até quatro meses. Para a realização da análise são utilizados dois balões volumétricos, em cada um são colocados volumes e concentrações definidas do reativo índigo. Um dos balões tem seu volume completado com água destilada, enquanto o outro tem seu volume completado com a amostra de água ozonizada. Ao reagir como o índigo trissulfonato de potássio, o ozônio provoca o descoramento da solução. A absorvância das soluções contidas nos dois balões são medidas em espectrofotômetro a $600 \pm 5 \mathrm{~nm}$ e cálculos adequados fornecem a quantidade de ozônio residual presente na amostra. (LANGLAIS; RECKHOW; BRINK, 1991).

Quando este método é utilizado, a mudança na absorvância é observada com mais precisão usando um espectrofotômetro, embora um procedimento de comparação visual seja possível. A dose de ozônio deve ser ajustada para descolorir entre 20 e $90 \%$ do reativo índigo e a relação entre o volume do reagente e o volume da amostra com ozônio deve estar próximo de 4,5 (LANGLAIS; RECKHOW; BRINK, 1991).

Vários outros métodos espectrofotométricos têm sido propostos para a determinação de ozônio residual, como o Método Leuco Cristal Violeta (LCV), o Método Ácido Cromo Violeta k (ACVK) e o Método Índigo Carmim. As reações com a N, $\mathrm{N}$-dietil-p-fenilenodiamina (DPD) ou a o-toloidina também podem ser utilizadas, porém elas devem ser consideradas como testes qualitativos para detecção de presença de agentes oxidantes (LANGLAIS; RECKHOW; BRINK, 1991).

\section{Método iodométrico}

É o método utilizado para determinar a concentração de ozônio residual encontrado em plantas de tratamento de águas. Neste método, o íon de iodeto se oxida a iodo através da ação do ozônio em uma solução de iodeto de potássio. Todas as outras espécies oxidantes, além do ozônio, agem como interferentes ao método (USEP 1999; 
LANGLAIS; RECKHOW; BRINK, 1991).

\section{Radiação ultravioleta}

A radiação ultravioleta pode ser utilizada para determinar a quantidade residual em fase líquida a um comprimento de onda de 258-260 nm ou 253,7 nm, que pode ser obtido pelo uso de lâmpadas de mercúrio de baixa pressão e filtros espectrais (LANGLAIS; RECKHOW; BRINK, 1991).

\section{Dispositivos eletroquímicos}

Neste caso, amperímetros são utilizados para a medição contínua da concentração de oxidantes presentes na fase líquida, sendo comumente utilizados nas estações de tratamento de água potável (LANGLAIS; RECKHOW; BRINK, 1991).

\section{Mensuração do ozônio residual na fase gasosa}

\section{Método iodométrico}

O princípio do método é o mesmo utilizado para determinação de ozônio em meio aquoso; neste caso, a fase gasosa passa através de uma solução aquosa que contém excesso de iodeto de potássio, onde o ozônio oxida o íon iodeto. $\mathrm{O}$ óxido de nitrogênio é um exemplo de interferente ao método. Os efeitos de óxidos de nitrogênio podem ser eliminados passando-se o gás ozônio por absorventes como permanganato de potássio, que é específico para gás de óxido de nitrogênio. Porém, nenhum método iodométrico é recomendado para a determinação de ozônio em solução gasosa por causa da insegurança do método (USEPA, 1999; LANGLAIS; RECKHOW; BRINK, 1991).

\section{Análise amperométrica}

O ozônio é detectado na amostra pela reação de oxi-redução na solução, que contém iodeto de potássio. Estas reações ocorrem sobre a porção do catodo do eletrodo, nesta região o ozônio da amostra reage com íon iodeto. Analisadores amperométricos da fase gasosa estão comercialmente disponíveis. (LANGLAIS; RECKHOW; BRINK, 1991).

\section{Radiação ultravioleta}

A radiação ultravioleta também pode ser usada para determinar a quantidade residual de ozônio gasoso a um comprimento de onda $253,7 \mathrm{~nm}$, onde a absorvância é máxima. Instrumentos para medir a quantidade de ozônio através da absorção da radiação UV são fornecidos por vários fabricantes para concentrações de gás abaixo de $1 \mathrm{~g} / \mathrm{m}^{3}$ (CNTP). Em geral, estes instrumentos medem a quantidade de luz quando o ozônio está ou não presente na amostra. A diferença entre as duas leituras está relacionada diretamente à quantidade de ozônio presente (USEPA, 1999; LANGLAIS; RECKHOW; BRINK, 1991).

\section{Calorimetria}

A base teórica da calorimetria para medição do ozônio é baseada na entalpia da decomposição catalisada por este gás $(\mathrm{DH}=142,3 \mathrm{~kJ} / \mathrm{mol})$. A determinação calorimétrica do ozônioé independente de calibração. A temperatura observada difere entre o gás de entrada e o gás que reage na catalise. A diferença de temperatura é medida por meio do termopar localizado em uma célula isolada, sendo seu valor proporcional a concentração de ozônio na fase gasosa (LANGLAIS; RECKHOW; BRINK, 1991).

\section{Quimiofluorescência}

O método pode ser usado para a determinação de baixas concentrações de ozônio na fase gasosa. O ozônio na fase gasosa pode ser medido usando a reação de quimiofluorescência entre o etileno e o ozônio. Este método é específico para o ozônio e é satisfatório para medida de ozônio no ar ambiente (USEPA, 1999). 


\section{Processo de decomposição do ozônio e subprodutos gerados}

As temperaturas elevadas, a radiação ultravioleta ou a presença de agentes catalisadores podem acelerar o processo de decomposição do ozônio (LAPOLLI et al., 2003). O ozônio se decompõe mais rapidamente em valores de $\mathrm{pH}$ altos e em solução aquosa e forma vários tipos de oxidantes com diferentes reatividades. As alterações na eficiência do processo de desinfecção com variações no $\mathrm{pH}$ estão relacionadas com mudanças na taxa de decomposição do ozônio (LANGLAIS; RECKHOW; BRINK, 1991).

Os subprodutos da desinfecção são todos os componentes químicos que foram gerados como conseqüência do tratamento da desinfecção da água, em especial pela adição de agentes oxidantes, portanto são produtos que originalmente não estavam presentes na água bruta. Sua origem provém da reação entre os agentes oxidantes com os compostos orgânicos e inorgânicos presentes na água bruta (VIDAL, 2003).

A formação dos subprodutos depende principalmente do tipo de desinfetante utilizado, da concentração da matéria orgânica da água, da presença de compostos halogenados (principalmente os brometos) e catalisadores naturais, do $\mathrm{pH}$, da dose do desinfetante, do tempo de contato e da força iônica (VIDAL, 2003; DANIEL, 2001).

Segundo Di Bernardo e Dantas (2005) e USEPA (1999), a demanda de ozônio na água esta associada a diversos fatores condicionantes, sendo os principais listados abaixo:

- reação com a matéria orgânica natural, com a formação de aldeídos, ácidos orgânicos e outros compostos;

- oxidação de subprodutos orgânicos que são biologicamente degradados e podem ser medidos como carbono orgânico assimilável ou carbono orgânico dissolvido biodegradável;
- presença de compostos orgânicos sintéticos, sendo que alguns desses compostos podem ser oxidados e mineralizados sob condições favoráveis (para se obter a mineralização total a oxidação deve ocorrer);

- oxidação do íon brometo que conduz à formação do ácido hipobromoso, do íon hipobromito, do íon bromato, dos compostos orgânicos bromados e das bromoaminas;

- reação dos íons carbonato ou bicarbonato (comumente medidos como alcalinidade) com os radicais livres hidroxila, com a formação de radicais carbonatos.

Tanto na reação direta com ozônio molecular quanto na reação indireta, onde as espécies reativas são radicais, há formação de subprodutos derivados da aplicação do ozônio na água. A formação de subprodutos pelo ozônio é influenciada principalmente pela dose de ozônio aplicada e pelas características naturais da água. Os subprodutos são gerados devido à reação do ozônio com compostos inorgânicos, principalmente o brometo e orgânicos como a matéria orgânica natural, principalmente substâncias húmicas (VIDAL, 2003).

Os principais subprodutos da ozonização identificados no tratamento de águas superficiais e subterrâneas são: aldeídos alifáticos de baixa massa molar, em particular, formaldeído, acetaldeido, dialdeído glioxal, e ceto-aldeído-metil glioxal; ácidos, como oxálico, succínico, fórmico e acético; compostos bromados (íon bromato, bromofórmio, ácido acético bromado, bromopicrina, bromoacetonitrila); ácido pirúvico e peróxido de hidrogênio (DI BERNARDO; DANTAS, 2005; USEPA, 1999; LANGLAIS; RECKHOW; BRINK, 1991). Segundo Vidal (2003), outras espécies ainda podem ser formadas a partir de desinfecção com ozônio como carbono orgânico dissolvido biodegradável, peróxidos e epóxidos, nitrosaminas, fenol, quinonas e furanos.

As substâncias húmicas (destacando ácidos 
fúlvicos) e os ácidos hidrofílicos de baixa massa molar são os principais precursores de aldeídos, mas também contribuem em menor proporção uma série de outros compostos, incluindo aminoácidos. Os ácidos carboxílicos e cetoácidos podem vir da oxidação dos ácidos graxos de alta massa molar, da reação direta do ozônio com a matéria orgânica natural (principalmente os ácidos fúlvicos) e da oxidação de aldeídos. Os peróxidos orgânicos são rapidamente convertidos a peróxido de hidrogênio e compostos carbônicos após a ozonização. O peróxido de hidrogênio apresenta efeitos toxicológicos, por isso a Comunidade Européia tem sugerido um limite de tolerância rígido para esse composto, embora os resíduos gerados na ozonização normalmente se decomponham na rede de distribuição. (VIDAL, 2003).

O ozônio não forma compostos orgânicos halogenados quando usado como desinfetante de água contendo matéria orgânica natural. Porém, quando a água apresenta o íon brometo, ocorre a formação de subprodutos bromados tantoinorgânicos (bromato) como orgânicos (bromofórmio, ácidos carboxílicos bromados, bromoacetonitrila, etc.) (DI BERNARDO; DANTAS, 2005; RICHARDSON et al., 2000; RICHARDSON et al.,1999; USEPA, 1999).

Segundo Vidal (2003), os principais subprodutos bromados encontrados após a ozonização são o bromato, o bromofórmio, o brometo de cianogênio, o dibromoacetonitrilo, o dibromoacetona, o ácido acético bromado e as bromohidrinas. Os subprodutos orgânicos representam menos de $10 \%$ do total dos compostos bromados presentes na água, sendo que o bromato é o que reúne maior interesse devido ao seu poder carcinogênico.

Os principais parâmetros envolvidos na formação bromato são a dose de ozônio (em doses maiores se obtém maiores quantidades de bromato), a concentração dos íons brometo (maior concentração de brometo, há maior formação de bromato), o pH ( $\mathrm{pH}$ elevado há maior formação de bromato), a matéria orgânica natural e a alcalinidade.

\section{O ozônio como um sanitizante alternativo ao cloro}

Segundo Richardson (2003), o processo de desinfecção para obtenção de água potável foi o maior triunfo da saúde pública do século XX. Antes de seu uso generalizado, milhões de pessoas morriam por causa de doenças como cólera e febre tifóide. Após 1900, quando a desinfecção química da água começou a ser utilizada em larga escala, as mortes atribuídas aos patógenos veiculados pela água diminuíram drasticamente nos países desenvolvidos.

Atualmente, desinfecção de águas pode ser feita tanto por agentes químicos quanto físicos, sendo os agentes químicos mais comuns o cloro, o dióxido de cloro e o ozônio, além do peróxido de hidrogênio, do ácido acético, do bromo, do iodo, do permanganato de potássio e do cloreto de bromo. Como agentes físicos destacam-se a radiação $U V$, a radiação gama e a radiação solar (DI BERNARDO; DANTAS, 2005; LIBÂNIO, 2005).

Os agentes químicos utilizados para a desinfecção e potabilização da água têm a função de controlar doenças de veiculação hídrica e inativar organismos patogênicos. No entanto, surtos de doenças de veiculação hídrica no final do século XX, com os casos de Ontário no Canadá em 2000 (gastroenterite por E. coli), Milwauke nos Estados Unidos em 1993 (criptosporidíase) e Peru em 1991 (cólera), mostraram a necessidade da adequada desinfecção e do controle da veiculação de patógenos em água potável. A necessidade de uma constante reavaliação das técnicas de desinfecção de águas, bem como as preocupações com os subprodutos gerados a partir da desinfecção, tem conduzido à investigação e utilização de estratégias e agentes desinfetantes alternativos (RICHARDSON, 2003).

O desinfetante químico mais utilizado mundialmente na desinfecção para a produção de água potável é o cloro. Este agente é empregado como desinfetante primário na maioria das estações 
de tratamento de água superficial ou subterrânea. (SILVEIRA, 2004; DANIEL, 2001; JACANGELO; TRUSSELL, 2001). O efeito do cloro livre e combinado inativa bactérias pela alteração da permeabilidade da membrana celular, liberando os componentes citoplasmáticos para o meio (SILVEIRA, 2004; SHANG; BLATCHLEY, 2001).

Apesar da eficiência germicida do cloro contra bactérias e alguns vírus, a toxicidade potencial dos subprodutos da cloração torna o processo cada vez menos atrativo. Os compostos clorados têm algumas desvantagens que limitam crescentemente seu uso, tanto no tratamento de água quanto na indústria de alimentos, pois a cloração pode conduzir à formação de compostos organoclorados, trihalometanos
(THMs) e ácidos haloacéticos, que são mutagênicos, tóxicos e carcinogênicos em água, em alimentos ou em superfícies de contato (PRESTES, 2007; LAZAROVA; SAVOYE; JANEX, 1999).

A Tabela 3 compara as características dos processos de desinfecção com cloro e com ozônio, em relação à segurança, a remoção de microrganismos, ao residual tóxico, a formação de subprodutos, aos custos operacionais e de investimento. Segundo Lazarova, Savoye e Janex (1999), investimentos no processo de desinfecção por ozônio podem ser vantajosos em função da remoção de um numero maior de microrganismos, especialmente vírus e cistos de protozoários e da geração de subprodutos menos tóxicos.

Tabela 3. Comparação das características dos processos de cloração e de ozonização.

\begin{tabular}{lcc}
\hline Características & Cloração & Ozonização \\
\hline Segurança & + & ++ \\
Remoção de bactérias & ++ & ++ \\
Remoção de vírus & + & ++ \\
Remoção de protozoários ${ }^{1}$ & - & ++ \\
Residual tóxico & +++ & + \\
Subprodutos & +++ & + \\
Custos operacionais & + & ++ \\
Custos de investimento & ++ & +++ \\
\hline
\end{tabular}

-, nenhum; +, baixo; ++, médio; +++, alto.

${ }^{1}$ análise in vitro de Cryptosporidium spp.

Fonte: Lazarova, Savoye e Janex (1999).

Ao contrário do cloro, o ozônio não forma compostos orgânicos halogenados quando usado como desinfetante de água contendo matéria orgânica natural, mas pode formar outros subprodutos orgânicos e inorgânicos. Quando a água submetida a ozonização ou tratada com cloro ou cloraminas apresenta o íon brometo, ocorre a formação de subprodutos bromados de potencial carcinogênico (SOUZA, 2006; DI BERNARDO; DANTAS, 2005; SILVEIRA, 2004; RICHARDSON et al. 2000; USEPA, 1999; LANGLAIS; RECKHOW; BRINK,
1991).

Richardson et al. (2000) não identificaram a presença de subprodutos bromados em água tratada por ozônio. No entanto, quando níveis elevados de brometo $(1,0 \mathrm{ppm})$ foram adicionados à água antes da ozonização, um subproduto bromado foi gerado, a dibromoacetonitrila, enquanto que após a cloração, foi identificado um maior número de compostos contendo bromo e/ou cloro e em maior concentração. 
A complexidade da formação e do controle dos subprodutos da ozonização está relacionada a vários fatores, dentre eles a extensa variação dos parâmetros que caracterizam a água natural como o $\mathrm{pH}$ e a presença de radicais livres, além do próprio objetivo do tratamento que estabelece condições mais ou menos drásticas de ozonização (LANGLAIS; RECKHOW; BRINK, 1991; SOUZA, 2006). A geração de subprodutos pode ser minimizada, se a ozonização for adequadamente aplicada e se a água a ser tratada não apresentar níveis demasiadamente elevados de contaminação química e microbiológica.

Estudos provenientes da indústria de alimentos mostram que o uso de certos desinfetantes em altas concentrações está contribuindo para o surgimento de microrganismos resistentes a desinfecção. Bactérias expostas a altas concentrações de desinfetantes se tornam mais resistentes, promovendo a resistência cruzada dos microrganismos aos desinfetantes e antimicrobianos (SILVEIRA, 2004; LANGSRUD et al., 2003; DANIEL, 2001). Desinfetantes alternativos vêm sendo aplicados em substituição ou em combinação com o cloro, (PRESTES, 2007; SILVEIRA, 2004; DANIEL, 2001), sendo o ozônio utilizado em larga escala na Europa (DI BERNARDO; DANTAS, 2005; LIBÂNIO, 2005; RICHTER; AZEVEDO NETTO, 2005). Richardson (2003) apresenta uma revisão dos subprodutos de desinfecção e outros compostos contaminantes encontrados em água tratada por cloro e por desinfetantes alternativos.

\section{Efeito antimicrobiano do ozônio}

O ozônio é um poderoso agente oxidante, eficaz na inativação de bactérias, bolores, leveduras, vírus, protozoários, inclusive formas esporuladas e cistos de protozoários, que são mais resistentes (SOUZA, 2006; LAPOLLI et al., 2003; USEPA, 1999).

O ozônio inativa diversas bactérias, incluindo gram-negativas e gram-positivas, células vegetativas e formas esporuladas, além de componentes do envoltório celular, esporos fúngicos ou cápsideos virais, em concentrações relativamente baixas e em reduzido tempo de contato (PRESTES, 2007; KHADRE; YOUSEF; KIM, 2001; KIM; YOUSEF; DAVE 1999). A redução ou a inativação da população microbiana devido a ozonização depende da concentração de ozônio, do tempo de aplicação e do microrganismo envolvido.

O ozônio atua inicialmente na membrana celular, sendo a superfície da célula microbiana o primeiro alvo a ser atingido. Sua ação antimicrobiana é decorrente da oxidação de glicolipídeos, glicoproteínas e aminoácidos da parede celular, alterando a permeabilidade e causando sua rápida lise. O ozônio ataca também grupos sulfidrila de enzimas, ocasionando o colapso da atividade enzimática celular. Além disso, sua ação sobre o material nuclear dos microrganismos altera as bases púricas e pirimídicas dos ácidos nucléicos, como ocorre com alguns vírus, onde o ozônio destrói seu RNA além de alterar as cadeias polipeptídicas do cápsideo protéico (SILVEIRA, 2004; HUNT; MARIÑAS, 1999).

A Tabela 4 apresenta a eficiência antimicrobiana do ozônio comparada com a do cloro livre, cloraminas e dióxido de cloro.

$\mathrm{O}$ pH não apresenta influência direta na desinfecção de bactérias, vírus e protozoários, as alterações na eficiência do processo de desinfecção estão relacionadas com mudanças na taxa de decomposição do ozônio em função do $\mathrm{pH}$. Sabe-se que em valores de $\mathrm{pH}$ mais elevados ocorre a formação de radicais livres de hidroxila, com elevado poder de oxidação, enquanto em valores menores que o $\mathrm{pH}$ neutro, a eficiência da desinfecção tem sido creditada ao ozônio molecular (DI BERNARDO; DANTAS, 2005; LANGLAIS; RECKHOW; BRINK, 1991). 
Tabela 4. Eficiência antimicrobianal de agentes desinfetantes a $5{ }^{\circ} \mathrm{C}$.

\begin{tabular}{lcccc}
\hline Microrganismo & \multicolumn{2}{c}{ Eficiência antimicrobiana do desinfetante (mg.min/L) } \\
\cline { 2 - 5 } & $\begin{array}{c}\text { Cloro livre } \\
(\mathbf{p H ~ 6 - 7 )}\end{array}$ & $\begin{array}{c}\text { Cloraminas } \\
\mathbf{( p H ~ 8 - 9 )}\end{array}$ & $\begin{array}{c}\text { Dióxido de cloro } \\
\mathbf{( p H ~ 6 - 7 )}\end{array}$ & $\begin{array}{c}\text { Ozônio } \\
\text { (pH 6 -7) }\end{array}$ \\
\hline Escherichia coli & $0,034-0,05$ & $95-180$ & $0,4-0,75$ & 0,02 \\
Poliovírus & $1,1-2,5$ & $770-3740$ & $0,2-6,7$ & $0,1-0,2$ \\
Rotavírus & $0,01-0,05$ & $3810-6480$ & $0,2-2,1$ & $0,006-0,06$ \\
Fagof2 & $0,08-0,18$ & - & - & - \\
Cistos de Giárdia lamblia & $47->150$ & - & - & $0,5-0,6$ \\
Cistos de Giardia muris & $30-630$ & 1400 & $7,2-18,5$ & $1,8-2,0$ \\
\hline
\end{tabular}

${ }^{1}$ Eficiência antimicrobiana (C.t), medida em função da concentração do desinfetante $(C)$ e do tempo requerido para inativação (t) de $99 \%$ dos microrganismos

Fonte: Hooff (1987) apud Langlais, Reckhow e Brink (1991).

Com o aumento da temperatura, o ozônio se torna menos solúvel e menos estável em água, entretanto as taxas de desinfecção e de oxidação química permanecem relativamente estáveis, a eficiência da desinfecção parece ter pouca influência da temperatura até $30{ }^{\circ} \mathrm{C}$ (DI BERNARDO; DANTAS, 2005; USEPA; 1999). Estudos mostram que um aumento na temperatura de 0 a $30{ }^{\circ} \mathrm{C}$ pode reduzir a solubilidade do ozônio e aumentar significativamente sua taxa de decomposição, porém não há nenhum efeito na taxa de desinfecção de bactérias (DI BERNARDO; DANTAS, 2005; LANGLAIS; RECKHOW; BRINK, 1991).

Sabe-se que a taxa de destruição de microrganismos aumenta com o aumento da temperatura (VIDAL, 2003; LAPOLLI et al., 2003; LANGLAIS; RECKHOW; BRINK, 1991). De acordo com a teoria de van't Hoff-Arrhenius, a temperatura determina, em parte, a taxa à qual o desinfetante se difunde através da superfície do microrganismo e a sua taxa de reação com o substrato (LANGLAIS; RECKHOW; BRINK, 1991). Quando ocorre um aumento de temperatura, o ozônio torna-se menos solúvel e menos estável em água, porém a taxa de reação com o substrato orgânico dos microrganismos aumenta (LAPOLLI et al., 2003; LANGLAIS; RECKHOW; BRINK, 1991).

\section{Ação sobre as bactérias}

A inativação das bactérias pelo ozônio pode ser considerada uma reação de oxidação de vários constituintes celulares. O primeiro alvo da oxidação é a membrana celular, mas há evidencias de que o ozônio aja também, sobre a atividade enzimática das bactérias. A oxidação e a inativação pelo ozônio são muito rápidas, além de não específicas em relação aos constituintes celulares, existindo dados que evidenciam a ação do ozônio sobre as bases púricas e pirimídicas dos ácidos nucléicos da Escherichia coli (LAPOLLI et al., 2003).

O efeito bactericida do ozônio já foi documentado para uma grande variedade de microrganismos, incluindo bactérias gram-positivas e gramnegativas. As bactérias gram-negativas possuem maior sensibilidade ao ozônio quando comparadas com as bactérias gram-positivas, pois possuem menor quantidade de peptídeoglicano em sua parede celular (RUSSEL; HUGO; AVLIFFE, 1999).

A Tabela 5 apresenta os resultados de diversos 
experimentos que demonstram a eficácia do ozônio condições de tratamento.

na redução da população bacteriana, sob diversas

Tabela 5. Eficácia da aplicação do ozônio na redução da população bacteriana, sob diversas condições.

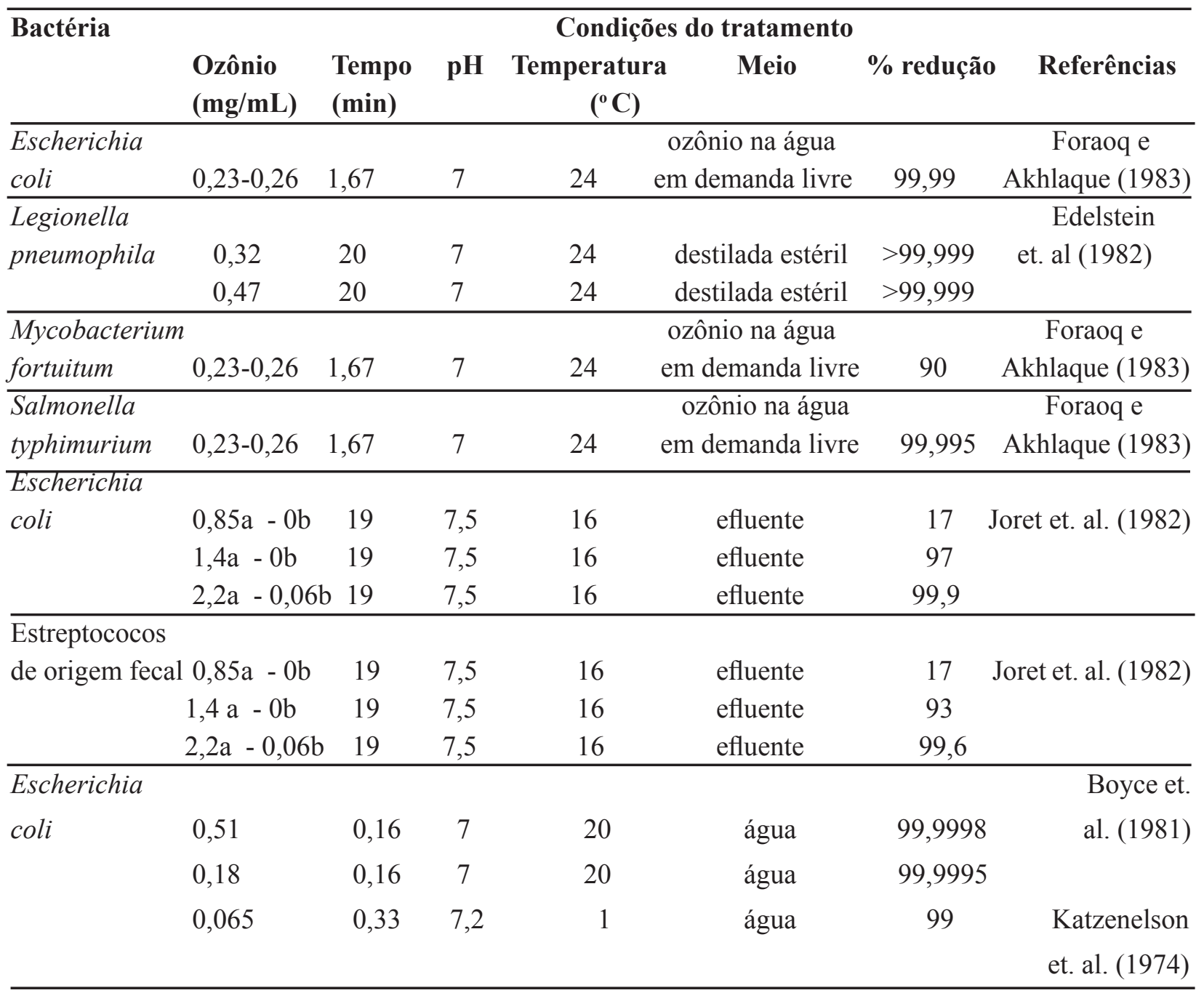

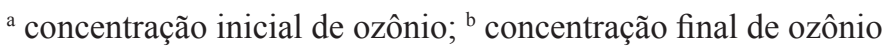

Fonte: Wickramanayake (1991).

A forma esporulada da bactéria é mais resistente à inativação que a forma vegetativa. $\mathrm{Na}$ forma vegetativa, uma das bactérias mais sensíveis à ação do ozônio é a $E$. coli, sendo mais resistentes à inativação os gêneros Staphylococcus e Streptococcus (cocos grampositivos), Bacillus (bacilos gram-positivos) e Mycobacteria (bacilos gram-positivos) (VIDAL, 2003; LANGLAIS, RECKHOW; BRINK, 1991).
Entre os bacilos gram negativos, o ozônio é especialmente efetivo contra a Legionella pneumophila, na concentração de $0,21 \mathrm{mg} / \mathrm{L}$ de ozônio em contato de mínimo $5 \mathrm{~min}$, sendo sua inativação de 99 \%. (LANGLAIS; RECKHOW; BRINK, 1991). A Legionella pneumophila é um patógeno que habita águas naturais ou tratadas, sendo originalmente parasita de amebas de água doce podendo, porém atingir o homem, 
causando um tipo de pneumonia que não tem tratamento eficaz com a utilização de penicilinas ou cefalosporinas (CORREIA et al., 2005).

O ozônio foi avaliado como método alternativo na sanitização de galões de água de 20 litros. A experiência consistiu na análise comparativa entre trinta galões sem tratamento e outros trinta galões desinfectados com água ozonizada, numa concentração de $4 \mathrm{mg} / \mathrm{L}$ de ozônio por 2 minutos. As amostras foram avaliadas quanto à contagem total de microrganismos aeróbios mesófilos heterotróficos, ao número mais provável (NMP) de coliformes totais e E. coli e testes qualitativos da presença de Staplyloccocus aureus e Pseudomonas spp em $100 \mathrm{~mL}$ de água enxaguatória dos galões. A contagem média de microrganismos aeróbios heterotróficos no estágio de pré-lavagem foi de $5,7 \mathrm{UFC} / \mathrm{cm}^{2}$ de área interna do galão, enquanto que após o tratamento com água ozonizada foi de 0,003 $\mathrm{UFC} / \mathrm{cm}^{2}$. Em relação às análises de coliformes totais e $E$. coli, o resultado foi de $<1 \mathrm{NMP} / \mathrm{mL}$ de solução enxaguatória. Todas as amostras após a sanitização com ozônio apresentaram resultados negativos para Pseudomonas spp., enquanto apenas $13,3 \%$ das amostras apresentaramse positivas para Staphylococcus aureus (CARDOSO et. al., 2003).

Considerando microrganismos associados aos alimentos, Kim, Yousef e Dave (1999) relataram a eficácia do ozônio contra Pseudomonas fluorescens, Leuconostoc mesenteroides, Listeria monocytogenes e Escherichia coli O157:H7. Os autores verificaram que todos os microrganismos foram inativados de 1,5 a 5 ciclos logarítmicos para uma concentração de ozônio entre 1 e 1,5 $\mathrm{mg} / \mathrm{L}$ com 15 segundos de exposição ao gás, sendo a Listeria monocytogenes o microrganismo que apresentou a maior redução de sua população.

\section{Ação sobre os fungos}

Os fungos são contaminantes comuns em alimentos e são responsáveis por perdas financeiras industriais e comerciais (SERRA et al., 2003). A ozonização é bastante efetiva contra fungos e micotoxinas, porém os fungos tendem a ser mais resistentes que as bactérias na forma vegetativa (RUSSEL; HUGO; AVLIFFE, 1999; KIM; YOUSEF; DAVE, 1999). Ainda assim, Wickramanayake (1991) relata que os fungos são facilmente atingidos pela ação do ozônio e em menor período de tempo do que bactérias como Escherichia coli, Staphylococcus aureus e Bacillus spp.

Segundo Kim, Yousef e Dave (1999), as concentrações de 0,6 a 1,5 ppm de ozônio têm ação contra o crescimento de bolores em ovos conservados a $0,6{ }^{\circ} \mathrm{C}$ e $90 \%$ de umidade relativa. As leveduras também são inativadas pelo ozônio e parecem ser mais sensíveis que os bolores. De acordo com os mesmos autores, a população de Candida parapsilosis diminuiu quando exposta a 0,23 - 0,26 ppm de ozônio por um tempo de 1,67 min. O efeito antimicrobiano do ozônio aumenta com o aumento da temperatura, da umidade relativa e o tempo de tratamento para $C$. parapsilosis e Kluyveromyces marxianus e atua estendendo a fase lag e a fase exponencial de Hansenula anomala e K. marxianus.

Os efeitos do ozônio na redução da população de Candida parapsilosis e Candida tropicalis em água podem ser observados na Tabela 6 . 
Tabela 6. Eficácia da aplicação do ozônio na redução de fungos, na água em demanda livre.

\begin{tabular}{lcccccrr}
\hline & \multicolumn{6}{c}{ Condições do tratamento } & \\
\cline { 2 - 6 } Fungo & Ozônio(mg/ml) & Tempo(minutos) & $\mathbf{p H}$ & Temperatura $\left({ }^{\circ} \mathbf{C}\right)$ & \% redução & Referências \\
\hline Cândida & $0,23-0,26$ & 1,67 & 7 & 24 & 99,8 & Foraoq e \\
parapsilosis & & & & & & Akhlaque (1983) \\
Candida & 0,02 & 0,30 & 7,2 & 20 & 99 & Kawamura et. \\
tropicalis & 1 & 0,08 & 7,2 & 20 & 99 & al.(1986) \\
\hline
\end{tabular}

Fonte: Wickramanayake (1991).

Ação sobre os vírus

Os vírus em geral são muito mais resistentes ao ozônio do que as bactérias vegetativas, porém menos resistentes que as bactérias esporuladas. Já os vírus na forma de fagos são bastante sensíveis ao ozônio (VIDAL, 2003; USEPA, 1999; LANGLAIS; RECKHOW; BRINK, 1991).

Os vírus patogênicos geralmente apresentam um tempo de permanência bem maior no ambiente do que as bactérias. O ozônio age sobre as proteínas que compõem o capsídeo viral, ocorrendo o comprometimento da capacidade infecciosa do vírus, uma vez que essas proteínas são responsáveis pela fixação do vírus na célula hospedeira. Altas concentrações de ozônio podem destruir completamente o capsídeo (LAPOLLI et al., 2003; LANGLAIS; RECKHOW; BRINK, 1991).

A resistência de seis vírus entéricos foi avaliada em uma concentração residual de $0,15 \mathrm{mg} \mathrm{O}_{3} / \mathrm{L} \mathrm{em}$ água, a um $\mathrm{pH}$ de 7,2 e temperatura de $20{ }^{\circ} \mathrm{C}$. Os resultados mostraram que dos vírus avaliados, o mais resistente foi o Poliovirus 2, seguido do Echovirus,
Poliovirus 1, Coxsakievirus B5, Echovirus 5, Coxsakievirus A9. Foi observado também, que quanto maior os valores da concentração residual do ozônio em água, da temperatura e do $\mathrm{pH}$, menor foi a resistência do vírus a inativação (DI BERNARDO; DANTAS, 2005).

A Tabela 7 demonstra o efeito do ozônio na redução da contaminação de água com Poliovirus 1, Coxsackievius A9 e Bacteriophage f2.

\section{Ação sobre os protozoários}

A resistência de microrganismos ao ozônio ou qualquer agente de desinfecção é influenciada pela espécie e pela forma que os mesmos aparecem no meio. Os cistos de protozoários são bem mais resistentes que a forma livre (LAPOLLI et al., 2003). Sabe-se também que os cistos de protozoários são mais resistentes do que as bactérias vegetativas e os vírus (USEPA, 1999; LANGLAIS; RECKHOW; BRINK, 1991). 
Tabela 7. Eficácia da aplicação do ozônio na redução de vírus, sob diversas condições.

\begin{tabular}{|c|c|c|c|c|c|c|c|}
\hline \multirow[t]{2}{*}{ Vírus } & \multicolumn{6}{|c|}{ Condições do tratamento } & \multirow[t]{2}{*}{ Referências } \\
\hline & $\begin{array}{r}\text { Ozônio } \\
(\mathrm{mg} / \mathrm{ml})\end{array}$ & $\begin{array}{l}\text { Tempo } \\
\text { (min) }\end{array}$ & $\mathbf{p H}$ & $\begin{array}{c}\text { Temperatura } \\
\left({ }^{\circ} \mathrm{C}\right) \\
\end{array}$ & $\begin{array}{c}\text { Condições } \\
\text { da água }\end{array}$ & \% redução & \\
\hline \multirow[t]{2}{*}{ Poliovirus 1} & $0,23-0,26$ & 1,67 & 7 & 24 & ozônio na água & 99,7 & Foraoq e \\
\hline & & & & & em demanda livre & & Akhlaque (1983) \\
\hline \multirow[t]{3}{*}{ Poliovirus 1} & 0,13 & $<0,3$ & 7,2 & 5 & água & 99 & \multirow{3}{*}{$\begin{array}{l}\text { Drinking Water } \\
\text { e Health (1980) }\end{array}$} \\
\hline & 0,50 & 0,245 & 7 & 24 & água & 99 & \\
\hline & 10 & 0,042 & 7 & 25 & água & 99 & \\
\hline \multirow[t]{3}{*}{ Poliovirus 1} & 0,2 & 9 & 4 & 20 & água & 99 & \multirow{3}{*}{$\begin{array}{c}\text { Harakeh e } \\
\text { Butler (1985) }\end{array}$} \\
\hline & 0,2 & 10 & 7,2 & 20 & água & 75 & \\
\hline & 0,2 & 10 & 9 & 20 & água & 80 & \\
\hline Coxsackievirus & 0,144 & 0,16 & 7 & 20 & água & $>98$ & Boyce et. al \\
\hline A9 & 0,035 & 0,16 & 7 & 20 & água & $>98$ & (1981) \\
\hline Bacteriophage & 0,40 & 0,16 & 7 & 20 & água & $>99,97$ & Boyce et. al. \\
\hline $\mathrm{f} 2$ & 0,41 & 0,16 & 7 & 20 & água & $>99,995$ & (1981) \\
\hline
\end{tabular}

Fonte: Adaptado de Wickramanayake (1991).

A membrana celular dos cistos é destruída pelo ozônio, que inicialmente afeta a parede celular, tornando-a mais permeável e possibilitando que o ozônio penetre no interior dos cistos e prejudique as membranas do plasma, chegando a afetar os componentes estruturais (DI BERNARDO; DANTAS, 2005; USEPA, 1999).

O ozônio tem se mostrado muito eficaz na inativação de cistos de Giárdia e Criptosporidium, ambos protozoários resistentes ao cloro (SILVEIRA, 2004; COSTA; DANIEL, 2002). A Giardia lamblia tem uma sensibilidade ao ozônio que é semelhante à forma esporulada da Mycobacteria. Os cistos de Naegleria e de Acanthomoeba são muito mais resistentes ao ozônio (e todos os outros desinfetantes) que os cistos de Giardia (USEPA, 1999). Dados mostram que oocisto de Cryptosporidium é o protozoário mais resistente ao ozônio (USEPA, 1999; LANGLAIS; RECKHOW; BRINK, 1991). Um estudo mostrou que oocistos de Cryptosporidium são aproximadamente 10 vezes mais resistentes ao ozônio que a Giardia (USEPA, 1999).

A Tabela 8 demonstra a eficiência do ozônio frente a Naegleria gruberi, a Giardia muris e a Giardia lamblia, sobre condições de aplicação diferenciadas. 
Tabela 8. Eficácia da aplicação do ozônio na redução de protozoários em água em pH 7

\begin{tabular}{lcccc}
\hline Protozoários & \multicolumn{4}{c}{ Condições do tratamento } \\
\cline { 2 - 5 } Ozônio $(\mathbf{m g} / \mathbf{m l})$ & Tempo $(\mathbf{m i n})$ & Temperatura $\left({ }^{\circ} \mathbf{C}\right)$ & \% redução \\
\hline Naegleria gruberi & 0,55 & 7,8 & 5 & 99 \\
& 2 & 2,1 & 5 & 99 \\
Giardia muris & 0,3 & 4,3 & 25 & 99 \\
& 1,2 & 1,1 & 25 & 99 \\
& 0,15 & 12,9 & 5 & 99 \\
Giardia lamblia & 0,7 & 2,8 & 5 & 99 \\
& 0,03 & 9,0 & 25 & 99 \\
& 0,15 & 1,8 & 25 & 99 \\
& 0,1 & 5,3 & 5 & 99 \\
& 0,5 & 1,1 & 5 & 99 \\
& 0,03 & 5,5 & 25 & 99 \\
\hline
\end{tabular}

Fonte: Wickramanayake (1984) apud Wickramanayake (1991).

\section{Aplicação do ozônio no processamento de alimentos}

Muitos processos da indústria de alimentos são propícios à utilização do ozônio. São exemplos de aplicações a ozonização de produtos agrícolas durante o armazenamento e o transporte e a sanitização da água de lavagem dos alimentos, equipamentos e materiais das embalagens (GRAHAM, 1997).

A inativação de microrganismos pelo ozônio é menos efetiva quando aplicada diretamente sobre a superfície do alimento do que o ozônio em demanda líquida. A inativação da microbiota em alimentos por ozônio depende muito da natureza e da composição da superfície dos alimentos, do tipo de contaminação microbiana, bem como o grau de associação de microrganismos com alimentos (KIM; YOUSEF; DAVE, 1999).

A aplicação do ozônio em vários países inclui a desinfecção e remoção de odores desagradáveis, sabor e cor da água. Nos Estados Unidos é considerado como uma substância GRAS (Generally Recognized as Safe) para água engarrafada e alimentos. Pode ser utilizado como agente de maturação de vinhos e cidras e na sanitização de recipientes para bebidas. É também utilizado para preservar ovos e na descontaminação de carcaças de animais e seus cortes (PRESTES, 2007; RUSSEL; HUGO; AVLIFFE, 1999; KIM; YOUSEF; DAVE, 1999).

O tratamento com ozônio diminuiu a contagem de mesófilos aeróbicos, coliformes e clostrídios sulfito redutores em carne transportada, além de melhorar a qualidade de armazenamento. Carcaças tratadas por 9 dias com 0,03 ppm de ozônio a $1,6^{\circ} \mathrm{C}$ e $95 \%$ de umidade relativa, não apresentaram crescimento bacteriano na superfície das peças (KIM; YOUSEF; DAVE, 1999). A utilização de água de lavagem ozonizada a 2,1 ppm pulverizada em carcaças de frango reduziu em $95 \%$ a contagem microbiana, sem afetar a coloração, o sabor e o odor da carne (TORRES; REGÊ FERREIRA; RÍMOLI, 1996).

Prestes (2007) avaliou o uso do ozônio na higienização de alface americana e crespa (Lactuca sativa L.), rúcula (Eruca sativa Mill.) e agrião (Nasturtium officinale $R$. Br.), com concentrações de $0,5,1,0$ e $1,5 \mathrm{mg} / \mathrm{L}$ pelo tempo de 1 minuto durante o processamento mínimo em comparação 
ao cloro. Neste estudo verificou-se que o ozônio reduziu efetivamente a contaminação por bolores e leveduras. Ao final do período de análise, os grupos tratados por ozônio apresentaram uma população média de bolores e leveduras notadamente menor que os grupos tratados por cloro.

Selma et al. (2007) avaliaram a eficiência da aplicação de ozônio na inativação de Shigella sonnei em alface. Os resultados mostraram que para 1 minuto de contato a 1,6 e 2,2 ppm de ozônio, a população de $S$. sonnei inoculada em água diminuiu de 3,7 e 5,6 $\log \mathrm{UFC} / \mathrm{mL}$, respectivamente.

O tratamento de frutas e vegetais com ozônio aumenta a vida-de-prateleira desses produtos. Em uvas houve redução do apodrecimento fúngico com tratamento de ozônio e armazenamento a frio (KIM; YOUSEF; DAVE, 1999).

Serra et al. (2003) utilizaram ozônio em uma câmara de maturação de queijos, mantida a $5{ }^{\circ} \mathrm{C}$ e umidade relativa até $80 \%$ durante 3 meses. Os autores empregaram uma taxa de geração de ozônio de $8 \mathrm{~g} / \mathrm{h}$ nos primeiros 5 dias, seguida por $4 \mathrm{~g} / \mathrm{h}$ nos próximos 5 dias e $8 \mathrm{~g} / \mathrm{h}$ a cada $40 \mathrm{~min}$ por período de uma hora durante o restante da maturação. Foi detectada uma redução efetiva de bolores no ambiente de maturação, porém a redução da contaminação nas superfícies da câmara somente ocorreu quando métodos de limpeza combinados com a ozonização foram utilizados.

Lanita e Silva (2008) observaram um bom desempenho no controle da biota contaminante durante o processo de maturação de queijo parmesão com a aplicação de ozônio na concentração de 0,03 ppm em câmara mantida a $11^{\circ} \mathrm{C}$ e umidade relativa entre $80-85 \%$ por 60 dias. Os resultados obtidos neste trabalho mostraram que o ozônio conseguiu reduzir a contagem de bolores e leveduras no ar da câmara de maturação. A ozonização propiciou uma redução de $2,8.10^{4}$ para $9,0 \mathrm{UFC} / \mathrm{cm}^{2}$ na contagem de bolores e leveduras na superfície de queijos, quando foi combinada com duas operações de lavagem superficial das peças. Uma redução ligeiramente menor também foi conseguida com o emprego de ozonização, uma lavagem inicial e aplicação de natamicina.

Campos et al. (2005) investigaram a eficiência do armazenamento de sardinha (Sardina pilchardus) através do uso de gelo fluído ozonizado, de gelo fluído e de gelo em escamas. O produto foi armazenado por 22 dias e para avaliar as alterações ao longo da estocagem foram utilizadas análises microbiológicas, químicas e sensoriais. De acordo com a análise sensorial, as sardinhas armazenadas em gelo fluído ozonizado tiveram uma vida de prateleira de 19 dias, enquanto as sardinhas armazenadas em gelo fluido e em gelo em flocos apresentaram uma vida de prateleira de 15 e 8 dias respectivamente. As sardinhas armazenadas em gelo fluido ozonizado apresentaram uma contagem mais baixa de aeróbios mesófilos, aeróbios psicrotróficos, anaeróbios, coliformes, microrganismos lipolíticos e proteolíticos no músculo da sardinha, assim como, na contagem superficial de mesófilos e psicrotróficos na pele da sardinha, quando comparados com o gelo fluido e o gelo em flocos. Os parâmetros químicos revelaram que o uso de gelo fluido reduziu a velocidade de formação de nitrogênio de bases voláteis totais (N-BVT) e de nitrogênio de trimetilamina (N-TMA). A combinação de gelo fluido ozonizado também permitiu um melhor controle do $\mathrm{pH}$ e da formação de N-TMA.

Kim et al. (2000) avaliaram a eficiência da aplicação em meio aquoso do ozônio, do peróxido de hidrogênio e do ácido ascórbico em solução salina sobre files de peixes. Os resultados mostraram que todos os tratamentos suprimiram o número inicial de coliformes totais e aeróbios psicrotróficos. Em todos os três tratamentos os resultados foram positivos, aumentando o tempo de vida-de-prateleira de 1,5 a 3 dias, com pequenas alterações na rancidez oxidativa e na cor. Para os files de peixe tratados com 10 ppm de ozônio ocorreu um aumento de $25 \%$ do tempo de vida-deprateleira. 
Öztekin, Zorlugenç e Zorlugenç (2006) avaliaram o efeito do ozônio gasoso sobre a microbiota de figos desidratados a uma concentração de 1,5 e 10 ppm, durante três e cinco horas de tratamento. Os resultados mostraram que todas as bactérias coliformes foram inativadas a 5 e 10 ppm de ozônio. Para reduzir a contagem de microrganismos nos figos era preciso no mínimo três horas de tratamento a $5 \mathrm{ppm}$. A aplicação de ozônio gasoso diminuiu a contagem total de aeróbios mesófilos e de leveduras em aproximadamente $38 \%$ e $72 \%$, respectivamente.

Guzel-Seydim, Greene e Seydim (2004) estudaram o ozônio como forma de higienização de uma indústria de laticínios, resultando em $84 \%$ de remoção de resíduos de leite, comparativamente a utilização de água a $40^{\circ} \mathrm{C}$ que removeu $51 \%$. O estudo concluiu que o ozônio pode ser usado na etapa de pré-enxague diminuindo o consumo de detergente. O ozônio também foi utilizado na água de chillers com a redução da contagem bacteriana. Chapas de aço inoxidável simulando o material de equipamentos de processamento de leite foram higienizados com água clorada e ozonizada, o ozônio reduziu em 99\% a população bacteriana.

\section{Limitações do uso do ozônio}

Segundo Souza (2006), uma das principais dificuldades da ozonização no tratamento de água é a impossibilidade do ozônio produzir residual que previna eventual contaminação. Outro problema apresentado é a geração de alguns subprodutos, que apesar de não incluírem compostos organoclorados (oriundos da reação da matéria orgânica com o cloro), ainda apresentam perigo potencial aos seres vivos e ao ambiente em decorrência da formação de compostos bromados em águas onde o íon brometo esteja presente.

Além disso, o ozônio não pode ser considerado universalmente benéfico aos alimentos, pois em altas concentrações, pode promover a degradação oxidativa, alterando o sabor e a coloração do produto alimentício (KIM; YOUSEF; DAVE, 1999).

\section{Reatividade}

A desvantagem da utilização de ozônio como desinfetante é sua instabilidade. O grande desafio é prever como o ozônio reage com a matéria orgânica, o gás pode oxidar o composto, ou espontaneamente, decompor-se em oxigênio e radicais livres. Os mecanismos de decomposição do ozônio são processos complexos, que dependem de fatores como os tipos de radicais formados em solução e o tipo de matéria orgânica presente. Portanto, é difícil generalizar que uma dada concentração particular de ozônio num determinado percentual será efetiva para inibição dos microrganismos presentes nos produtos alimentícios (LANGLAIS; RECKHOW; BRINK, 1991).

Depois do tratamento com 1,5 mg/L de ozônio, amostras de água que não apresentaram residual de ozônio permaneceram estéreis por mais que 1 mês. Porém, durante passagem por uma tubulação, observou-se a recontaminação e crescimento considerável de microrganismos (STALDER et al., 1976 apud KIM; YOUSEF; DAVE, 1999). Como desinfetante, o ozônio tem um efeito imediato, elimina a carga microbiana presente do alimento e na água, porém posteriormente pode haver uma recontaminação, pois o residual de ozônio é praticamente nulo.

\section{Deterioração da qualidade de alimentos}

A oxidação da superfície dos alimentos pode ser o resultado do uso excessivo de ozônio. Alguns autores alegam que o ozônio não é universalmente benéfico (KIM; YOUSEF; DAVE, 1999). Concentrações muito altas do gás podem causar oxidação na superfície de alimentos resultando na descoloração e alteração do sabor e odor. O ozônio também é capaz de mudar a coloração da superfície de frutas e legumes como pêssegos, cenouras, e brócolis (PRESTES, 2007; 
KIM; YOUSEF; DAVE, 1999). As alterações nos atributos sensoriais ou físico-químicos dependem da composição química do alimento, da dosagem de ozônio, e das condições do tratamento.

Estudos mostraram que o ozônio diminuiu o ácido ascórbico em brócolis e o conteúdo de tiamina em farinha de trigo. O ozônio teve um efeito negativo na qualidade sensorial de alguns produtos como grãos, especiarias e leite em pó, devido à oxidação de lipídios. Porém, outros investigadores demonstraram que o tratamento com ozônio melhorou a qualidade sensorial em carne de boi e de ovos e não alterou significativamente a qualidade sensorial de algumas frutas e legumes (KIM; YOUSEF; DAVE, 1999). Lanita e Silva (2008) não constataram o surgimento de processos adicionais de rancidez oxidativa em queijo parmesão submetido à ação do ozônio durante a maturação.

\section{Toxidade}

A toxidade é um critério de extrema importância para aprovar o ozônio no processamento de alimentos. Os efeitos primários do ozônio em humanos estão relacionados com o trato respiratório. Sintomas de toxidade incluem dor de cabeça, tontura, sensação de ardência nos olhos e garganta, sensação de odor pungente e tosse. Em baixas concentrações o ozônio não é um gás extremamente tóxico, mas em altas concentrações pode ser letal (RUSSEL; HUGO; AVLIFFE, 1999).

A aspiração direta do ozônio é extremamente perigosa, por sua alta toxidade ao ser humano. No entanto, a ingestão por intermédio de água ozonizada não apresenta perigo sério, pois a meiavida do ozônio dissolvido na água é relativamente curta (LAPOLLI et al., 2003). A inalação acidental do ozônio causa respiração acelerada, sendo que o grau dependerá do conteúdo inalado e do tempo de exposição ao ozônio. O paciente deve descansar imediatamente após o acidente para reduzir o efeito de sufocação, que é causado pela irritação do trata respiratório, devendo ser levado ao hospital o mais rápido possível (LANGLAIS; RECKHOW; BRINK, 1991).

Uma concentração de ozônio da ordem de 0,1 $\mathrm{mg} / \mathrm{L}$ pode causar irritação ao nariz, garganta e olhos. Pesquisadores alegam que concentrações de ozônio de 0,02 a $0,04 \mathrm{mg} / \mathrm{L}$ podem ser detectadas pelo ser humano e que a exposição prolongada a concentrações iguais ou superiores a $1,0 \mathrm{mg} / \mathrm{L}$ pode causar a morte. Uma exposição de uma hora a concentrações de 2, 4, 15 e $95 \mathrm{mg} / \mathrm{L}$ pode causar efeitos sintomáticos, irritantes, tóxicos e letais, respectivamente. Os efeitos tóxicos do ozônio pela inalação são manifestados nos pulmões. Uma variedade de danos extra-pulmonares também podem ser resultado da ação do ozônio e de seus produtos (KIM; YOUSEF; DAVE, 1999).

Como o ozônio se torna um gás tóxico acima de certas concentrações, limites máximos de exposição são definidos e as pessoas que trabalham em plantas de ozonização devem ser submetidas a revisões médicas regulares. Os limites de referência para a exposição humana ao ozônio que foram estabelecidos por alguns órgãos regulamentadores norte-americanos são apresentados na Tabela 9 (LANGLAIS; RECKHOW; BRINK, 1991). No Brasil, os limites de tolerância de ozônio em até 48 horas de trabalho por semana são de $0,08 \mathrm{~mL} /$ $\mathrm{m}^{3}$ ou de $0,16 \mathrm{mg} / \mathrm{m}^{3}$, segundo a NR 15 da Portaria MTB no 3.214, de 08 de junho de 1978, que aprova as Normas Regulamentadoras - NR - do Capítulo V, Título II, da Consolidação das Leis do Trabalho, relativas à Segurança e Medicina do Trabalho, (BRASIL, 1978). 
Tabela 9. Os níveis de referência para exposição humana ao ozônio.

\begin{tabular}{lll}
\hline Organizações & Níveis de Exposição & Tempo de Exposição \\
\hline OSHA - Occupational Safety and & máximo de $0,1 \mathrm{mg} / \mathrm{L}$ & 8 horas/dia \\
Health Administration & média de $0,1 \mathrm{mg} / \mathrm{L}$ & 8 horas/dia \\
ANSI/ASTM - American National Standards & máximo de $0,3 \mathrm{mg} / \mathrm{L}$ & 10 minutos/dia \\
Institute/American Society for Testing Materials & máximo de $0,1 \mathrm{mg} / \mathrm{L}$ & 8 horas/dia \\
ACGIH - Americam Conference of Government & máximo de $0,3 \mathrm{mg} / \mathrm{L}$ & 15 minutos/dia \\
Industrial Hygienists & máximo de $0,1 \mathrm{mg} / \mathrm{L}$ & 8 horas/dia \\
American Industrial Hygiene Association &
\end{tabular}

Fonte: Lapolli et al. (2003); USEPA (1999); Langlais; Reckhow e Brink (1991).

\section{Conclusão}

O ozônio é um agente antimicrobiano eficiente que tem grande potencial de uso na indústria de alimentos. A aplicação do ozônio durante o processamento e/ou estocagem aumenta a vida de prateleira dos produtos, porém é importante considerar a concentração aplicada, pois se esta for elevada pode causar danos oxidativos, odor desagradável e alteração na coloração do alimento. O ozônio quando comparado ao cloro é um potente sanitizante, que se decompõe rapidamente e não forma alguns dos subprodutos formados pela cloração como, por exemplo, os trialometanos (THMs). Ainda é importante ressaltar que a aplicação do ozônio requer alguns cuidados, por ser um gás extremamente tóxico em concentrações elevadas e por propiciar, assim como o cloro, a formação de compostos bromados em água quando em presença do íon brometo.

\section{Agradecimentos}

Os autores agradecem a FINEP - Financiadora de Estudos e Projetos.

\section{Referências}

BRASIL. Ministério do Trabalho e Emprego. Portaria MTB $n^{\circ}$ 3.214, de 08 de junho de 1978. Aprova as Normas Regulamentadoras - NR - do Capítulo V, Título II, da Consolidação das Leis do Trabalho, relativas à
Segurança e Medicina do Trabalho. NR 15 - Atividades e Operações Insalubre - Anexo no 11. Disponível em: $<$ http://www010.dataprev.gov.br/sislex/paginas/05/ $\mathrm{mtb} / 15 . \mathrm{htm}>$. Acesso em: 9 set. 2008.

CAMPOS, C. A.; RODRIGUEZ O.; LOSADA V.; AUBOURG S. P.; BARROS-VELAZQUEZ, J. Effects of storage in ozonized slurry ice on the sensory and microbial quality of sardine. International Journal of Food Microbiology, Amsterdam, v. 103, n. 2, p. 121-130. 2005.

CARDOSO, C. C.; VEIGA, S. M. O. M.; NASCIMENTO, L. C.; FIORINI, J. E.; AMARAL, L. A. Avaliação microbiológica de um processo de sanificação de galões de água com a utilização do ozônio. Ciências e Tecnologia dos Alimentos, Campinas, v. 23, n. 1, p. 5961, jan./abr. 2003.

CORREIA, A. G.; SOARES, A. P. R.; CASTRO, R. A.; GURGEL, T. B. A.; SOUZ, L. B. S.; SANTANA, W. J.; COUTINHO, H. D. M. Fatores genéticos associados à virulência de Legionella spp. Revista Medica Ana Costa, Santos, v. 10, n. 3, p. 51-56, 2005.

COSTA, H.; DANIEL, L. (Coord.). Desinfecção de efluentes sanitários, remoção de patógenos e remoção de substâncias nocivas. Vitória: PROSAB, 2002.

DANIEL, L. A. (Coord.). Processo de desinfecção e desinfetantes alternativos na produção de água potável. São Carlos: Rima, 2001. 139 p.

DI BERNARDO, L.; DANTAS, A. D. B. Métodos $e$ técnicas de tratamento de água. São Carlos: Rima, 2005. v. 2,784 p.

GRAHAM, D. M. Use of ozone for food processing. Food Technology, Chicago, v. 51, n. 6, p. 72-75, 1997.

GUZEL-SEYDIM, Z. B.; BEVER JUNIOR, P. I.; GREENE, A. K. Efficacy of ozone to reduce bacterial 
populations in the presence of food components. Food Microbiology, London, v. 21, n. 4, p. 475-479, 2004.

GUZEL-SEYDIM, Z. B.; GREENE, A. K.; SEYDIM, A. C. Use of ozone in the food industry. Lebensmittel Wissenschaft und Technologie, San Diego, v. 37, n. 4, p. 453-460, 2004.

HUNT, N. K.; MARIÑAS, B. J. Inactivation of Escherichia coli with ozone: chemical and inactivation kinetics. Water Research, Kidlington, v. 33, n. 11, p. 2633-2641, 1999.

JACANGELO, J.; TRUSSELL, R. International report - water and wastewater disinfection: trends, issues and practices. Water Science and Technology, London, v. 2, n. 3, p. 147-157, 2001.

KHADRE, M. A.; YOUSEF, A. E.; KIM, J. G. Microbiological aspects of ozone applications in food: a review. Journal of Food Science, Malden, v. 66, n. 9, p. 1242-1252, 2001.

KIM, J. G.; YOUSEF, A. E.; DAVE, S. Application of ozone for enhancing the microbiological safety and quality of foods: a review. Journal of Food Protection, Des Moines, v. 62, n. 9, p. 1071-1087, 1999.

KIM, T. J.; SILVA, J. L.; CHAMUL, R. S.; CHEN, T. C. Influence of ozone, hydrogen peroxide, or salt on microbial profile, TBARS and color of channel catfish fillets. Journal of Food Science, Malden, v. 65, n. 7, p. 1210-1213, 2000.

KUNZ, A.; FREIRE, R. S.; ROHWEDDER, J. J. R.; DURAN, N.; MANSILLA, H.; RODRIGUEZ, J. Construção e otimização de um sistema para produção a aplicação de ozônio em escala de laboratório. Química Nova, São Paulo, v. 22, n. 3, p. 425-428, 1999.

LANGLAIS, B.; RECKHOW, D. A.; BRINK, D. R. Ozone in water treatment: application and engineering. Chelsea: AWWARF and Lewis Publishers, 1991. 568 p.

LANGSRUD, S.; SIDHU M. S.; HEIR E.; HOLCK, A. L. Bacterial disinfectant resistance: a challenge for the food industry. International Biodeterioration \& Biodegradation, Kidlington, v. 51, n. 4, p. 83-290, 2003.

LANITA, C. S.; SILVA, S. B. Uso de ozônio em câmara industrial para controle de bolores e leveduras durante a maturação de queijo tipo parmesão. Brazilian Journal of Food Technology, Campinas, v. 11, n. 3, p. 182-189, 2008.

LAPOLLI, F. R.; SANTOS, L. F.; HÁSSEMER, M. E. N.; AISSE, M. M.; PIVELI, R. P. Desinfecção de efluentes sanitários por meio da ozonização. In. GONÇALVES, R. F. (Coord.). Desinfecção de efluentes sanitários, remoção de organismos patógenos e substâncias nocivas: aplicação para fins produtivos como agricultura, aqüicultura e hidropônica. Vitória: PROSAB, 2003. p. 169-208.

LAZAROVA, V.; SAVOYE, P.; JANEX, M. Advanced wastewater disinfection technologies: state of the art and perspectives. Water Science Technology, London, v. 40, n. 4-5, p. 201-213, 1999.

LIBÂNIO, M. Fundamentos de qualidade de tratamento de água. Campinas: Átomo, 2005. 444 p.

ÖZTEKIN, S.; ZORLUGENÇ, B.; ZORLUGENÇ, F. K. Effects of ozone treatment on microflora of dried figs. Journal of Food Engineering, Kidlington, v. 75, n. 3, p. 396-399, 2006.

PRESTES, E. B. Avaliação da eficiência do ozônio como sanitizante em hortaliças folhosas minimamente processadas. 2007. Tese (Doutorado em Tecnologia de Alimentos) - Universidade Estadual de Campinas, Campinas.

RICE, R. G.; ROBSON, C. M.; MILLER, G. W.; HILL, A. B. Uses of ozone in drinking water treatment. Journal of the American Water Works Association, Denver, v. 73, n. 1, p. 44-47, 1981.

RICHARDSON, S. D. Disinfection by-products and other emerging contaminants in drinking water. Trends in Analytical Chemistry, London, v.22, n. 10, p. 666-684, 2003.

RICHARDSON, S. D.; THRUSTON JR.; CAUGHRAN, T. V.; CHEN, P. H.; COLLETTE, T. W.; SCHENCK, K. M.; LYKINS JR. B. W.; RAV-ACHA, C.; GLEZER, $\mathrm{V}$. Identification of new drinking water disinfection by: products from ozone, chlorine dioxide, chloramine, and chlorine. Water, Air, and Soil Pollution, Dordrecht, v. 123, n. 1/4, p. 95-102, 2000.

RICHARDSON, S. D.; THRUSTON JUNIOR, A. D.; CAUGHRAN; T. V.; CHEN; P. H.; COLLETTE T. W.; FLOYD, T. L.; SCHENCK, K. M.; SCHENCK, K. M. B.; LYKINS JUNIOR, B. W. B.; SUN, G. R. C.; MAJETICH, G. Identification of new ozone disinfection by-products in drinking water. Environmental Science and Technology, Iowa City, v. 33, n. 19, p. 3368-3377, 1999.

RICHTER, C. A.; AZEVEDO NETTO, J. M.Tratamento de água: tecnologia atualizada. São Paulo: Edgard Blücher, 2005. $332 \mathrm{p}$.

RUSSEL, A. D.; HUGO, W. B.; AVLIFFE, G. A. J. Principles and practice of disinfection, preservation and sterilization. 3. ed. Oxford: Blackwell Science, 1999. $826 \mathrm{p}$.

SELMA, M. V.; BELTRAN, D.; ALLENDE, A.; 
CHACON-VERA, E.; GIL, M. I. Elimination by ozone of Shigella sonnei in shredded lettuce and water. International Journal of Food Microbiology, London, v. 24, n. 5, p. 492-499. 2007.

SERRA, R.; ABRUNHOSA, L.; KOZAKIEWICZ, Z.; VENANCIO, A.; LIMA, N. Use of ozone to reduce molds in a cheese ripening room. Journal of Food Protection, Des Moines, v. 66, n. 12, p. 2355 - 2358, 2003.

SHANG, C.; BLATCHLEY, E. Chlorination of pure bacterial cultures in aqueous solution. Water Research, Kidlington, v. 35, n. 1, p. 244 - 254, 2001.

SILVEIRA, I. C. T. Cloro e ozônio aplicados a desinfecção de efluente hospitalar tratado em contadores biológicos rotatórios, com avaliação de efeitos tóxicos em DAPHNIA SIMILIS. 2004. Dissertação (Doutorado em Recursos Hídricos e Saneamento Ambiental) Universidade do Rio Grande do Sul, Porto Alegre.

SOUZA, J. B. Avaliação de métodos para desinfecção de água, empregando cloro, ácido peracético, ozônio e o processo de desinfecção combinado ozônio/cloro. 2006. Tese (Doutorado em Hidráulica e Saneamento) Universidade de São Paulo, São Carlos.

TORRES, E. A. F. S.; REGÊ FERREIRA, A. F.; RÍMOLI, C. D. Estudos das propriedades desinfetantes do ozônio em alimentos. Higiene Alimentar, Itapetininga, v. 10, n. 42, p. 8-23, 1996.

USEPA - United States Environmental Protection Agency. Alternative disinfectants and oxidants guidance manual. 1999. Disponível em: <http://www.epa.gov/ OGWDW/mdbp/alternative_disinfectants_guidance. pdf $>$. Acesso em: 30 maio 2008 .

VIDAL, F. J. R. Processo de potabilización del agua e influencia del tratamiento de ozonización. Madrid: Ediciones Díaz de Santos, 2003, 253 p.

WICKRAMANAYAKE, G. B. Disinfection and sterilization by ozone. In: BLOCK, S. S. (Ed.). Disinfection and sterilization and preservation. 4. ed. Philadelphia: Lea and Febiyer, 1991. p. 182-190. 